Participatory Educational Research (PER)

Special Issue 2015-I, pp. 145-154, June, 2015

Available online at http://www.partedres.com

ISSN: 2148-6123

http://dx.doi.org/10.17275/per.15.spi.1.10

\title{
Public Participation in the Environmental Undertaking in the Trans Pacific Partnership a Listening Approach.
}

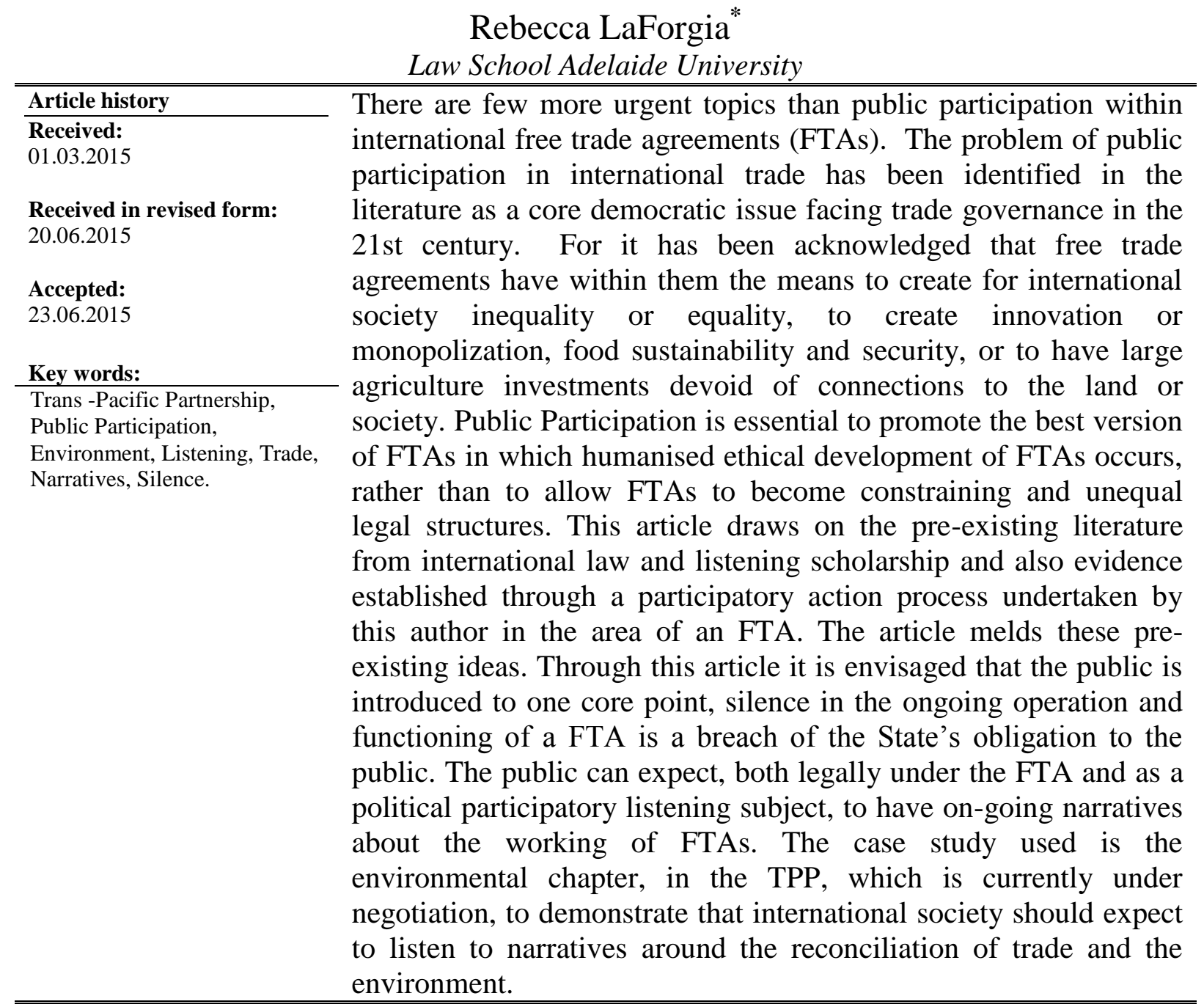

\section{Introduction}

There are few issues more pressing for the environment, for economic equality, for relationships between the governed and the governing than that the public develops a sensibility and expectation of narratives under FTAs (Nanz and Steffek, 2004) Trade agreements operate across time, geography, economics, services, goods, food, health, forms of production, and will directly and indirectly create labour and environmental practices.

\footnotetext{
*Correspondence: Rebecca.laforgia@adelaide.edu.au
} 
(Cho, 2012; Hirsch, 2008). If the public has a listening expectation of FTAs, in the context of the TPP in particular, they will participate through creating a demand on the State to seed and grow information so that the terrain of international trade agreements can become fertile for international society, rather than the dead grey wooden thicket of intersecting obligations, which reveal nothing but silence.

The article draws from pre-existing literature. There has already been scholarship that theorises the need for public participation in international trade Charnovitz (2004) and Bonzon (2008). There is also scholarship, which sees the importance of trade narratives and information being produced (Cottier 2010). On the other hand there is scholarship in the area of listening, which perceives the social and political act of listening as being a powerful means of participating and living (e.g., Bickford, 1996; Dobson, 2014). This article is therefore not conceptually original. Rather it melds these two areas, and argues that public participation in trade, if it is perceived as desiring to listen to narratives from trade agreements, gives an emotional connection to trade agreements which can enhance the production of these trade narratives. Through introducing the listening frame in the context of trade the participatory public is linked to the sensibilities of writers such as Hirsch $(2008, \mathrm{p}$. 280) who stated: '... trade is conceived of as a specific type of social interaction' and seen as 'transmitting intangibles that are the essence of society: ideas value, identity and a shared experience and community'. A legitimate form of public participation in trade is therefore to expect the production of narratives so that as a society we can listen to such intangible ideas from FTAs rather than only silence or economic modelling by the State.

To colloquially introduce this idea of a listening expectation as a form of participation, consider the statement of Prentice on the poet Sylvia Plath and the recordings she had made of her poetry:

...the nature of sound recording is such that the listener is immersed in what they hear, and recordings are full of rich detail that cannot be captured by other media. The Plath recording contains so much more than her words: her mid-Atlantic accent, her personality, and even something of her attitude to her own work.

Mr Will Prentice (Head of Technical Services for the British Library cited in Malvern, 2015, p.15)

Prentice made this statement when discussing the need to retain the Plath's recordings which would become fragile and open to destruction over time; however, this observation by Prentice also contained an emotion, an expectation and yearning to hear the voice of Plath. Intuitively, this is understandable. The desire is itself a form of participation; it is a desire not only to participate by reading Plath's poems, or speaking about the poems, but also by listening to the recordings. However, this desire has within itself an inbuilt sensibility and sensitivity to loss (Butt, 2010). In the context of music Butt wrote: 'We can surely assume that virtually all music in the human world presupposes that someone will hear it - otherwise there would be no reason, unless very obscure, to create it' Butt $(2010$, p. 6). This article wants to take this particular form of participation (i.e., an expectation to listen) and transpose this with respect to a contemporary and highly contested trading agreement; that is, the TPP (Capling \& Ravenhill, 2011). There are currently 12 negotiating states: the United States of America, Australia, Brunei, Canada, Chile, Japan, Malaysia, Mexico, New Zealand, Peru, Singapore, and Vietnam, for more information see Fergusson, McMinimy, \& Williams, (2015). This article asks the question inspired by Butt (2010) that is why create this legal structure if there are not open narrative for the public to hear? 
Cho (2012) is representative, however of the important scholarship which is analysing, in the context of international trade ( his work is in the context of World Trade Organisation) a sociological approach, which emphasises narratives and communication. There are other authors seeking to emphasis themes of justice and sociology generally, for example (Carmody, Garcia \& Linarelli (2012) and Hirsch (2008). Cho (2012, p. 351) makes the point that more communication is required:

[R]ationalism neither recognizes nor offers a solution to the developmental disparity amongst WTO members. Under the new sociological paradigm, such developmental disparity is treated as a serious problem to the development of discursive spheres.

Public participation as a listening expectation can be seen therefore to compliment, or as a pre-condition or perhaps a driver for the narratives, which underpin Cho's (2012) concept of discursive interaction. However one of the most poignant calls for being attuned to 'the secret' (or as it is termed in this article the idea of silence) came from Orford (2006, p. 173) who, in the context of international trade, stated:

'... sacrificial responsibility involves a singular relationship with an unknown other. The Christian tradition, this other is named God, but in the tradition of economic law we might name this other 'the market'. This responsibility can be acted upon only in silence, in the solitude and in the absence of knowledge. Responsibility in this tradition describes the split relationship of an individual to the public world of universal principles, and to the unknown other to whose demands the individual must respond in secret.

The argument in this article is that individuals as public participants can attune themselves to such 'sacrifices', loss and silence through perceiving participation not only as per its traditional mechanisms in international trade, which characterises participation as the struggle and right to speak and be heard. A 'listening expectation' as a frame for participation has the additional capacity of attuning oneself to Orford's (2006) idea of the sacrifices of trade (including environmental sacrifices). The silence around trade and the environment under FTAs should be perceived as actively 'hanging in the air' still continuing to contain all the possible constructive narratives that could have been raised, requiring only an opportunity for the listening public to demand non-silence and production of narratives by the State. A constructivist view of trade has been implicitly endorsed by Lang (2006, p. 114), Cho (2012, pp. $321 \& 343)$ and Carmody (2008, p. 527).

\section{Section One: Introducing Public Participation and the TPP}

The TPP is a significant trade agreement which is currently being negotiated, (Lewis, 2011 , p. 27) and, under some estimates, it will cover $40 \%$ of the worlds GDP. It will have wide-ranging obligations, including impacts on services, the environment and health (Kelsey, 2010; Murphy, 2010, p. 189). It has been secretly negotiated; that is, the public, while being able to access stakeholder events, have not had access to the treaty text as it was being formed (except via Wiki leaks). The agreement is of great geo-political importance. The TPP, which is under negotiation, is not simply a trade agreement; rather, it is significant statement by the United States in respect of its presence in Asia (Lewis, 2011, p. 37). Although given the debates at the time of writing regarding the approval of Fast Track Authority, in the United States, the future of the TPP and the question of when it will come into effect has become unclear. It is however meant to signal to China, particularly in light of China's recent creation of the Asian Infrastructure Investment Bank, that the United States also has a significant economic presence in the region (Anu, 2015, 14 April). Thus, the TPP has the opportunity to 
create and indeed cement forms of governance (democratic, open or closed) as a dominant norm (LaForgia, 2012, 5 September).

Public Participation can occur at different points in time (e.g., in negotiating with respect to text upon its release, but before it has been formalised and when the treaty has not yet been operationalised). There has been an extensive literature in international trade on the need for public participation in international trade generally (Bonzon, 2008, p. 751; 2010, 287). There has also been in the literature clear arguments for the importance of information under trade agreements once they are created see for example Cottier $(2010$, p. 43) and also the application of Cottier's work by Bonzon. (2010, pp. 287, 290-291). The aim of this article is to conceive of public participation itself as a listening public desiring these trade narratives. The article therefore can be seen as a constructive melding of existing observations in the literature from trade and listening scholarship, rather than an original approach.

As both the United States and Australia are negotiating the TPP their experience under a current trade agreement they are both party to, the on-going Australia United States Free Trade Agreement (2005) (AUSFTA). This agreement therefore serves as a significant precedent for the form and content of the TPP. Public participation in trade often peaks at the point at which the treaty is being negotiated. Members of the public may perceive themselves as being alienated or galvanised to argue against specific obligations; thus the role of the public is clearly to both agitate and direct activity. This has been described in the context of the AUSFTA (Ranald, 2010, p. 41). In the context of the AUSFTA, after the agreement had been finalised and was in operation, public participation waned; there were no regular calls for consultations and narratives were not available, despite being promised. This situation has generally been referred to as a 'democratic deficit'. Nanz and Steffek (2004, p. 314) stated:

The increasing capacity of international governance regimes to generate law and regulations binding all citizens has come to conflict with this problem of democratic legitimacy. The idea of democratic legitimacy is that the citizens decide for themselves the content of the laws that organize and regulate their political association. Separating the process of rule-making from politically accountable institutions, global governance is argued to suffer a massive "democratic deficit".

This article aims to connect to the idea that the TPP could contain narratives (i.e., stories of reconciliation in relation to the environment and trade) and that these narratives are for the public generally (Cho, 2012). Participation as listening can create this relationship and expectation, that is returning to the poignant observation of (Butt, 2010, p.6) who writing of listening and music considered there was a conceptual link, that is '.. all music in the human world presupposes that someone will hear it-otherwise there would be no reason, unless very obscure, to create it' We can ask a Butt (2010) inspired question of trade agreement and ask, why create these legal architectures unless there are open narratives that international society can listen to?

\section{Section 2 The listening literature}

In this section, a listening lens for participation will be introduced; this is not a new idea and has been explored by many writers (e.g., Bickford, 1996; Dobson, 2014). Listening as a form of political and social participation and engagement is gaining in momentum (Bickford, 1996; Dobson, 2014; Bodie, Cyr, Pence, Rold \& Honeycutt, 2012; Gehrke, 2009; and Koskinen \& Lindström, 2013). However, while it is gaining momentum as a political and social area of study, Crawford (2009, p. 533) noted: 'we are still discovering what the 
thresholds of human listening might be, quantitatively and qualitatively. The studying of the listening subject is just beginning'.

Several themes can be identified in relation to the listening approach. This complements the powerful image of the expectation of listening to Plath's rendition of her poems. One emotion that is developed in listening is a culture of attentiveness to something (Crary, 1999 as cited in Crawford, 2009). Drawing on Crary's work, Crawford (2009, pp. 525, 532) made the following two statements, first: 'The ways in which we intently listen to, look at, or concentrate on anything have a deeply historical character' and, second, we have 'an ongoing crisis of attentiveness'. Similar observations are common in the literature; for example, in reviewing the work of Bickford, Catt- Oliason (2005, p. 49) noted: 'In recent years listening theorists have turned a good deal of attention to listening in the political public sphere' and that 'listening develops two significant qualities: consideration towards the other and a quality of "mindful[ness]", Similarly, Bickford (1996, p. 145), drawing on the work of Weil, noted: 'attention requires a profound stilling of the self'. Bickford (1996, p. 145)

Koskinen and Lindström (2013, p. 147) offered the following analysis of the meaning of listening:

Listening involves opening up to you, allowing your speech to enter and flow through me. Listen has its base in the Latin adire [obedience, obey], which means that there is a connection between listening and obedience whether it focuses on the other, on responsibility. Listening, as opposed to hearing, does not involve placing the other in conformity with ourselves, but instead entails a creation of a space to receive that which is difficult, different and radically strange, to allow the alterity of the other resonate. Looking and listening make space of the unthinkable, the unimaginable Other. Listening means to bear witness... .

However, listening and the environment were also considered by Holifield (2013, p. 55) who, drawing on the work of Naess (1987) and his concept of the 'ecological self', stated:

Perhaps in this time of crisis there is an opportunity to develop a listening perspective that has a newfound curiosity about both the individual's inner life and the interweaving of the individual-in-relation with the more-than-human -community, a listening for an ecological self.

In the context of listening, Dobson (2014) recently melded the political and environmental together. After detailing the category of listening in the political context, Dobson overlaid the politics of listening with a particular sensibility in the context of the environment. In relation to environmental listening Dobson $(2014$, p. 159) wrote: 'The consequences of ignoring this vitality amount to a self fulfilling prophecy in which the assumption that the non-human is dead, mute, simultaneously fuels an unsustainable attitude towards it and legitimates a sensory shutdown that forecloses the possibility of the discovery of non- human vitality'.

Thus, there are a series of participatory attributes that arise for the listening public, including ideas such as attentiveness (Crary, 1999 as cited in Crawford, 2009) or bearing witness (Koskinen \& Lindström, 2013) as relating to the desire to listen. Just as voice has a series of attributes (e.g., to express, have an opinion or argue), listening participation has a series of active and important participatory outcomes.

Section 3: Silence under the AUSFTA 
The previous section outlined the attributes of a listening expectation. This section outlines silences; that is, the lack of there being anything to which to listen. This section considers the lack of any narratives produced under the AUSFTA around trade and the environment. Through an adapted participatory action research approach which was influenced by the work of Romm (2010, p. 315). Also, although it is not explicitly identified as participatory action research, the work of Wiener (2009) and Venzke (2009) in the area of international relations and international legal context respectively, have nevertheless produced and interrogated political and legal meaning in innovative and important ways which also influenced the approach of engaging with meaning directly under the AUSFTA.

The AUSFTA clearly required and envisaged forms of dialogue that did not come to pass. Section 19.5 of Chapter 19 of the AUSFTA required that an opportunity be created for the public 'to provide views, recommendations, or advice on matters related to the implementation' of the environmental chapter. Further, section 19.6 of Chapter 19 of the AUSFTA stated: 'Each Party shall take into account, as appropriate, public comments and recommendations it receives regarding these ongoing cooperative environmental activities undertaken by the Parties' and 'The Parties shall, as appropriate, share information with each other and the public regarding their experiences in assessing and taking into account the positive and negative environmental effects of trade agreements and policies' (emphasis added).

There are many possible readings for this undertaking. It is not an unusual undertaking in the context of international law that, as an interpretative enterprise, is inherently open (Venzke, 2009). However, it can be seen from reading the text that each party would be sharing their 'experiences'. This is an essential point and these experiences could also be labelled 'trade narratives' (a phrase that is closer to poetry than to any expression or description of an outcome that would be provided by a number). Accordingly, article 19 envisages a sharing of experiences, including difficulties and the reconciliation of the positive and negative aspects of the environment under trade. This evokes the idea of an ongoing truthful narrative.

However, under this treaty, this practice of reporting as promised by this legal obligation, has not been realised. Indeed, there been no publically available and ongoing consultation. In answer to an enquiry made by the author of this article, the Australian Department of Foreign Affairs and Trade (DFAT) (personal communication, 1 December 2010) stated:

Prior to entry into force of the Agreement, Australia conducted a review of the environmental effects of the AUSFTA, as part of a broader study commissioned by the Australian Government on the impacts of the FTA. This review by the Centre for International Economics was finalised in April 2004 and is publicly available at: http://www.thecie.com.au/content/publications/CIE-economic_analysis_ausfta.pdf

This report concluded that the underlying causes of environmental degradation are not linked to trade.

If the listening as participation section above is considered and the comment of Holifield (2013, p. 55, drawing on Naess 1987) that 'the interweaving of the individual-in relation with the more-than- human community, a listening for an ecological self' is recalled, it can be observed that despite the promise of sharing experiences that evoke the idea of 'interweaving' there were no revelations.

Despite the explicit statement in Chapter 19 of the AUSFTA that there would be regard for '... their experiences in assessing and taking into account the positive and negative 
environmental effects of trade agreements and policies', there was no collection of narratives, no sense of attention and no reflection on the balance between trade and the environment. Indeed, there was silence.

The next section considers the observations on participation by listeners and the existence of silence under the trade treaty environment and melds these two categories in the context of the TPP. The aim being that, even if a State remains non- compliant under the environmental chapter of the TPP (should it be successfully negotiated), if participation is perceived as listening, then the public will, similar to the poem at the beginning of this article, feel the loss of not hearing the narratives of stories of trade and environment. Further, participation, by the expectant listener, will drive a deep participatory desire to hear and will thus create an ongoing discontent around any continual silence from the State.

\section{Section 4: The Effect of the Expectant Listener as a form of Participation under the TPP}

The re-conception of public participation as an expectation of listening in the context of trade has been an aim of this article. This flows from listening scholarship which is increasing as a form of political expression in the literature for example Dobson (2014). Traditionally, the failure and silence under Chapter 19 of the AUSFTA could be characterised as non-compliance (Lester, 2011, 12 April) and also $\operatorname{OECD~(2007,~p.~89):~'Information~on~}$ actual amounts spent on environmental co-operation activities under RTAs is not easily available'. However, if, rather than using technical legal language, the idea of a loss of narratives or information is conceived as a loss of listening moments, then a more emotional connection can be created with the non-compliance of the legal obligations. This lack of compliance would then evoke an absence of a fulsome rendition of experiences. It is a similar point to Cottier (2010, p. 43) who considers that trade committee's could provide more information, but the listening framework for participation has overlaid this observation of a information deficit, with a sense of expectation and loss inspired from the listening scholarship.

Considering the negotiation of the TPP brings into force the idea that public participating, as conceived under the listening framework, has several positive effects. The first is a highlight a general sensibility of listening to qualitative narratives. One of the only ways in which the environmental and social impact can truly be assessed is to hear about the stories of trade. Evoking the idea of on-going conversations that move beyond 'rationalism' as discussed by Cho (2012). Thus, both the expectation of listening and the development of narratives that can be heard are particularly important at this time in the $21^{\text {st }}$ century where social and ecological pressures are at their prime. If there is but one story under the TPP committees of the environmental impact of the agreement, then we start to listen to the sensibilities of what is happening. This one story can be built upon; a discourse can be created with it and more can be learnt from it than could be learnt through only numbers.

Currently, trade agreements are not 'sold' to the public in the form of narratives or social qualitative stories. This is no accident-government and states often have the right to negotiate in secret and merely say to the public: 'Look, this agreement will be good for society, economically'. Each TPP negotiating state would have said that to its own population. Thus, the trade agreement has been presold to the public predominantly on the basis of economic growth and prosperity. The tragic consequence of this is if the TPP comes into force and has an impact on the environment, there is no public expectation that the trade 
agreement is a rich source of complex narratives to understand or explain the effects. The listening framework heightens the expectation that the trade agreement itself is the best legal mechanism for creating interesting, complex stories and that legal committees should be set up under the agreement to produce narratives (Cottier, 2010, p.43). This would create an expectation in the public that there was much to listen to under the agreement. However, trade is often not seen in this light; it does not have a natural narrative. Thus, the expectation of 'listening' as a form of participation is an important cultural change to show that the TPP can hold stories of integration between societies.

The TPP, if it comes into force, will have an environmental chapter or undertakings; however, the particular form of these commitments as contained in the TPP, are at the time of writing unknown. The narratives from this undertaking should be listened to, if only (and this is inspired by the quotation in relation to Plath at the beginning of this article) to see 'our own attitude' towards our trade agreements, our planet our society. However, unless a listening expectation exists for an emotional and participating public, then silence will remain.

The loss of narratives also impacts on the creation of international communities; for example, if the environmental impacts in a state and between all the parties to an agreement are not heard and if these experiences are not shared, then a potential connection is lost. As Beard (2009, p. 19) argued: 'I do not, as an ethical being, listen only to you; I listen with you, as well. Some acts of listening create community. The choices we make in selecting what we listen to can create a community'. The choice and expectation of listening by public participation in the environmental chapter of the TPP, should it come into effect, will create a listening community with all the people of all the states that are a party to the agreement. Listening to the environmental chapter of the TPP, should it come into effect, will also create a community with the environment that sustains all the people of the states that are a party to the agreement.

\section{References}

Anu, A. K. (2015, 14 April). AIIB miles ahead of TPP in promoting integration. East Asia Forum. Retrieved from http://www.eastasiaforum.org/2015/04/14/aiib-miles-ahead-oftpp-in-promoting-integration/.

Beard, D. (2009). A broader understanding of the ethics of listening: Philosophy, cultural studies, media studies and the ethical listening subject. The International Journal of Listening 23(1), 7- 20.

Bickford, S. (1996). Listening, conflict, and citizenship: The dissonance of democracy. Ithaca, NY: Cornell University Press.

Bodie, G., Cyr, K., Pence, M., Rold, M. \& Honeycutt, J. (2012). Listening competence in initial interactions I: Distinguishing between what listening is and what listeners do. International Journal of Listening, 26, 1-28.

Bonzon, Y. (2008). Institutionalizing public participation in WTO decision making: Some conceptual hurdles and avenues. Journal of International Economic Law, 11, 751777.

Bonzon, Y. (2010). Options for public participation in the WTO: Experience from regional trade agreements. In D. P. Steger (Ed.). Redesigning the World Trade Organization for the twenty-first century (pp. 287-309). Ottawa: Wilfrid Laurier University Press.

Butt, J. (2010). Do musical works contain an implied listener? Towards the theory of musical listening. Journal of the Royal Musical Association, 135(S1), 5-18. 
Capling, A. \& Ravenhill, J. (2011). Multilateralising regionalism: What role for the transpacific partnership agreement? The Pacific Review 24, 553.

Carmody, C. (2008). A Theory of WTO law. Journal of International Economic Law, 11(3) $527-557$.

Carmody, C., Garcia F. J., \& Linarelli, J. (Eds). (2012). Global justice and international economic law: Opportunities and prospects. Cambridge: Cambridge University Press.

Catt-Oliason, J. (2005) Essay: On the dissonance of democracy: Listening, conflict, and citizenship. International Journal of Listening, 19, 48-50.

Charnovitz, S. (2004). Transparency in participation in the World Trade Organization. Rutgers Law Review, 56, 927-960.

Cho, S. (2012). Beyond rationality: A sociological construction of the World Trade Organization. Virginia Journal of International Law, 52, 321-354.

Cottier, T. (2010). A two-tier approach to WTO decision-making. In D. P. Steger (Ed.). Redesigning the World Trade Organization for the twenty-first century. Ottawa: Wilfrid Laurier University Press,

Crary, J. (2001). Suspensions of perception: attention, spectacle, and modern culture. Cambridge MA: MIT Press.

Crawford, K. (2009). Following you: Disciplines of listening in social media. Continuum: Journal of Media and Cultural Studies, 23(4): 525-535.

Dobson, A. (2014). Listening for democracy: Recognition, representation, reconciliation. Oxford, UK: Oxford: University Press.

Fergusson, I. F., McMinimy, M. A. \& Williams, B. R. (2015). The Trans-Pacific Partnership (TPP): Negotiations and issues for congress. (CRS Report No. R42694). Retrieved from Congressional Research Service. https://www.fas.org/sgp/crs/row/R42694.pdf.

Gehrke, P. (2009). Introduction to listening, ethics, and dialogue: Between the ear and the eye: A synaesthetic introduction to listening ethics. International Journal of Listening, 23(1), 1-6.

Hirsch, M. (2008). The sociology of international economic law: Sociological analysis of the regulation of regional agreements in the world trading system. European Journal of International Law, 19, 277-299.

Holifield, B. (2013). Listening for an ecological self. Jung Journal, 7(1): 48-61.

Howse, R. (2002). From politics to technocracy - and back again: the fate of the multilateral trading regime. American Journal of International Law 96, $94-$.

Kelsey, J. (Ed.) (2010). No Ordinary Deal: Unmasking the Trans-Pacific Partnership Free Trade agreement. Sydney, Australia: Allen \& Unwin.

Koskinen, C. \& Lindström, U. Å. (2013). Listening to the otherness of the other: Envisioning listening based on a Hermeneutical reading of Lévinas' International Journal of Listening, 27(3), 146-156.

Lang, A. T. F. (2006). Reconstructing embedded liberalism: John Gerard Ruggie and constructivist approaches to the study of the international trade regime. Journal of International Economic Law, 9(1), 81-116.

LaForgia, R. (2012, 5 September). Submission regarding the inclusion of a Public Participation obligation within the TPP. Retrieved from http://dfat.gov.au/trade/agreements/tpp/submissions/Documents/tpp_sub_public_parti cipation_LaForgia_050912.pdf.

LaForgia, R. Submission to the Commonwealth Treaty-Making process inquiry by the Senate Standing Committee on Foreign Affairs, Defence and Trade. Retrieved from

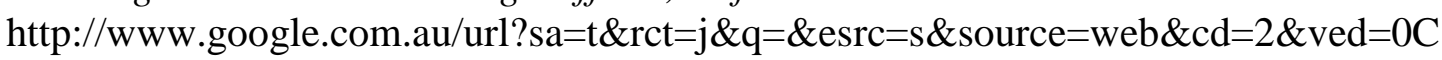
CMQFjAB\&url=http\%3A\%2F\%2Fwww.aph.gov.au\%2FDocumentStore.ashx\%3Fid $\% 3 \mathrm{D} 5021 \mathrm{e} 342-5 \mathrm{df6}-4 \mathrm{ffd}-\mathrm{ad} 68-$ 
559d10ebb6e3\%26subId\%3D303996\&ei=N9x0VcGyEsyA8gWzi4K4Dw\&usg=AFQj CNGrAakUPL-R9-XYYQmNwi4RKt6vTw\&bvm=bv.95039771,d.dGc.

Lester, S. (2011, 12 April). Measuring the Benefits of Trade Agreements. International Economic Law and Policy Blog. Retrieved from http://worldtradelaw.typepad.com/ielpblog/2011/04/measuring-the-benefits-of-tradeagreements.html.

Lewis, M. K. (2011). The Trans-Pacific Partnership: New paradigm or wolf in sheep's clothing? Boston College International and Comparative Law Review, 34, $27-52$.

Malvern, J. (2015, May 28). Race against time to save voices of yesteryear. The Times, reproduced in The Australian, p. 15.

Murphy, T. Government procurement and labour issues. In J. Kelsey (Ed.) (2010). No Ordinary Deal: Unmasking the Trans-Pacific Partnership Free Trade agreement. Sydney, Australia: Allen \& Unwin.

Nanz, P. \& Steffek, J. (2004). Global Governance, Participation and the Public Sphere. Government and Opposition, 39(2), 314-335.

OECD (2007). Chapter 5: Environment and Regional Trade Agreements.

Orford, A. (2006). International law and its others. Cambridge: Cambridge University Press.

Orford, A. (2006). Trade, human rights and the economy of sacrifice. In A. Orford (Ed.), International law and its others (pp. 156-196). Cambridge: Cambridge University Press.

Ranald, P. (2010). The politics of the Trans-Pacific Partnership in Australia. In J. Kelsey (Ed.) No Ordinary Deal: Unmasking the Trans-Pacific Partnership Free Trade agreement. Sydney, Australia: Allen \& Unwin.

Romm, N. R. A. (2010). New Racism: Revisiting Researcher Accountabilities. Netherlands: Springer.

Venzke, I. (2009). Legal contestation about 'enemy combatants': On the exercise of power in legal interpretation. Journal of International Law and International Relations, 5(1), $155-184$.

Wiener, W. (2009). Enacting meaning-in-use: Qualitative research on norms and international relations. Review of International Studies, 35, 175-193. 